\title{
Improving Mathematics Learning Outcomes for Whole Numbers Materials Through an Active Learning Model Type Index Card Match (Icm) for Class 1 Students at State Elementary School Cibentang 01 Semester I 2019/2020 Academic Year
}

\section{Nunung Setyawati}

\author{
SD Negeri Cibentang 01 \\ nunungsetyawati6@gmail.com
}

\section{Article History}

received 3/12/2020

\begin{abstract}
This research is a collaborative classroom action research with the research subject of teachers and students of class 1 SD Negeri Cibentang 01 totaling 22 students. The object of this research is the result of learning mathematics through an Active Learning model of Index Card Match type on whole numbers. This research was conducted for two cycles. The results showed an increase in mathematics learning outcomes after using the Index Card Match Active Learning model according to the syntax in the first cycle. The increase again occurred after modifications were made with discussion, the use of rewards, and the addition of quiz rules in the second cycle. The increase occurred in the cognitive value from 70.68 in the pre-cycle to 84.95 in the second cycle. The affective aspect increased from 2.47 (good) in the first cycle to 3.04 (good) in the second cycle. The use of the Active Learning model with the Index Card Match type until the second cycle obtained data $>75 \%$ of all students scored 70 so that the mathematics learning process using the Index Card Match type Active Learning model is considered to be able to improve student learning outcomes.
\end{abstract}

Keywords: active learning model, index card match, learning outcomes

\begin{abstract}
Abstrak
Penelitian ini merupakan penelitian tindakan kelas kolaboratif dengan subjek penelitian guru dan peserta didik kelas 1 SD Negeri Cibentang 01 sejumlah 22 peserta didik. Objek penelitian adalah hasil belajar matematika melalui model Active Learning tipe Index Card Match pada materi Bilangan cacah. Penelitian ini dilakukan selama dua siklus. Hasil penelitian menunjukkan adanya peningkatan hasil belajar matematika setelah menggunakan model Active Learning tipe Index Card Match sesuai sintaks pada siklus I. Peningkatan kembali terjadi setelah dilakukan modifikasi dengan diskusi, penggunaan reward, dan penambahan aturan kuis pada siklus II. Peningkatan terjadi pada nilai kognitif yaitu dari 70,68 pada pra siklus menjadi 84,95 pada siklus II. Aspek afektif mengalami peningkatan dari 2,47 (baik) pada siklus I menjadi 3,04 (baik) pada siklus II. Penggunaan model Active Learning tipe Index Card Match hingga siklus II diperoleh data $>75 \%$ dari seluruh peserta didik mendapat nilai $\geq 70$ sehingga proses pembelajaran matematika dengan menggunakan model Active Learning tipe Index Card Match dipandang dapat meningkatkan hasil belajar peserta didik.
\end{abstract}

Kata kunci : model active learning, index card match, hasil belajar

Social, Humanities, and Education Studies (SHEs): Conference Series https://jurnal.uns.ac.id/shes

p-ISSN 2620-9284

e-ISSN 2620-9292 


\section{PENDAHULUAN}

Matematika merupakan salah satu mata pelajaran yang diajarkan di Sekolah Dasar. Matematika mempunyai peranan dalam melatih penalaran peserta didik. Melalui matematika diharapkan peserta didik dapat menerapkannya dalam kehidupan sehari-hari. Selain itu, matematika merupakan salah satu ilmu yang selalu berkembang, baik dari sisi materi maupun manfaatnya bagi masyarakat. Oleh karena itu, matematika penting untuk dikuasai sejak dini. Diharapkan apabila peserta didik dapat menguasai matematika dengan baik, peserta didik juga dapat menguasai ilmuilmu yang lain dengan baik pula.

Metode pembelajaran yang digunakan guru biasanya adalah metode konvensional seperti ceramah. Metode tersebut membuat peserta didik pasif karena pembelajaran berpusat pada guru. Padahal keterlibatan peserta didik dibutuhkan agar peserta didik dapat menguasai konsep yang diberikan dengan baik.

Permasalahan dalam proses belajar mengajar juga terjadi di SD Negeri Cibentang 01, Kecamatan Bantarkawung, Kabupaten Brebes. Menurut pengamatan peneliti selama melaksanakan pengamatan di SD Negeri Cibentang 01, peneliti menemukan permasalahan yaitu rendahnya hasil belajar peserta didik dalam menyelesaikan soal matematika. Rendahnya hasil belajar peserta didik ini ditunjukkan dari nilai yang didapat pada saat Ulangan Harian Matematika . Kriteria Ketuntasan Minimal $(\mathrm{KKM})$ di SDN Cibentang 01 yaitu $\geq 70$. Hanya 14 dari 22 peserta didik atau berkisar $63,63 \%$ dari jumlah peserta didik mampu mendapatkan nilai sesuai dengan KKM, sedangkan 8 dari 22 peserta didik atau 36,37 \% dari jumlah peserta didik belum mampu mendapatkan nilai matematika sesuai dengan KKM.

Salah satu tipe atau metode pembelajaran dalam Active Learning ini adalah tipe Index Card Match (ICM). Model Active Learning tipe Index Card Match (ICM) adalah model pembelajaran aktif dengan menggunakan metode permainan mencari pasangan kartu. Dengan menggunakan metode permainan, diharapkan suasana pembelajaran yang aktif dan menyenangkan dapat terwujud. Seperti diungkapkan Monks, (Pitadjeng, 2006:95) bahwa anak dan permainan merupakan dua pengertian yang tidak dapat dipisahkan satu sama lain. Hal itu berarti bahwa anak-anak tidak dapat dipisahkan dari permainan.

Index Card Match merupakan salah satu metode dari strategi meninjau ulang (reviewing strategies) dalam Active Learning. Menurut Siberman, (2002:239) materi yang telah ditinjau (review) oleh peserta didik mungkin disimpan lima kali lebih dari materi yang tidak ditinjau. Diharapkan dengan melakukan peninjauan terhadap materi yang telah diajarkan, peserta didik menjadi lebih mudah untuk mengolah informasi yang diterimanya. Peserta didik juga dapat menyimpan informasi dalam jangka waktu yang lebih lama.

\section{LANDASAN TEORETIS DAN HIPOTESIS TINDAKAN}

\section{Hakikat Belajar Matematika}

Hakikat mempelajari matematika adalah mempertemukan pengetahuan subjektif dan objektif matematika melalui interaksi social untuk menguji dan merepresentasikan pengetahuan pengetahuan baru yang telah diperolehnya.

Melalui social negotiation processes maka rekonstruksi pembelajaran matematika dalam pembudayaannya menunjukkan proses yang jelas bahwa pengetahuan baru tentang matematika (new knowledge of mathematics) dapat berada pada lingkup sosial atau berada pada lingkup individu. Pengetahuan baru matematika pada lingkup sosial bersifat objektif dan pengetahuan baru pada lingkup individu bersifat subjektif. Dengan demikian, interaksi social dalam pembelajaran matematika menjadi penting untuk mendekatkan pengetahuan subjektif matematika menuju pengetahuan objektif. Hal demikian akan dengan mudah dipahami dan 
diimplementasikan jikalau guru yang bersangkutan juga memahami asumsi-asumsi yang disebut terdahulu.

2. Tinjauan tentang Pembelajaran Matematika.

Menurut Soedjadi (1999:1) matematika yang diajarkan di pendidikan dasar (SD dan SLTP) dan pendidikan menengah (SLTA) biasa disebut dengan matematika sekolah. Ebbutt dan Straker (Marsigit, 2011:8) mendefinisikan matematika sekolah sebagai: (1) kegiatan matematika merupakan kegiatan penelusuran pola dan hubungan, (2) kegiatan matematika memerlukan kreativitas, imajinasi, intuisi dan penemuan, (3)kegiatan dan hasil-hasil matematika perlu dikomunikasikan, (4) kegiatan problem solving merupakan bagian dari kegiatan matematika, (5) algoritma merupakan prosedur untuk memperoleh jawaban-jawaban persoalan matematika, dan (6) interaksi sosial diperlukan dalam kegiatan matematika.

\section{Tinjauan tentang Model Active learning tipe Index Card Match}

Model pembelajaran adalah kerangka konseptual yang melukiskan prosedur yang sistematis dalam mengorganisasikan pengalaman belajaruntuk mencapai tujuan belajar tertentu, dan berfungsi sebagai pedomanb agi para perancaang pembelajaran dan para pengajar dalam merencanakan aktivitas pembelajaran (Winataputra, 2005:3). Kemudian dalam bukunya Rusman (2010:133), Joyce \& Weil berpendapat bahwa model pembelajaran adalah suatu rencana atau pola yang dapat digunakan untuk membentuk kurikulum (rencana pembelajaran jangka panjang), merancang bahan-bahan pembelajaran, dan membimbing pembelajaran dikelas atau yang lain

Menurut Hisyam Zaini (2008 :14) , pembelajaran aktif adalah suatu pembelajaran yang mengajak peserta didik untuk belajar secara aktif. Pembelajaran aktif (active learning) dimaksudkan untuk mengoptimalkan penggunaan semua potensi yang dimiliki oleh anak didik, sehingga semu aanak didik dapat mencapai hasil belajar yang memuaskan sesuai dengan karakteristik pribadi yang mereka miliki. Disamping itu active learning juga dimaksudkan untuk menjaga perhatian peserta didik/anak didik agar tetaptertuju pada proses pembelajaran.

Salah satu bentuk strategi pembelajaran aktif adalah metode pembelajaran Index Card Match (pencocokan kartu indeks). Index Card Match atau Pencocokan Kartu Indeks ini merupakan cara aktif dan menyenangkan untuk meninjau ulang materi pelajaran. Cara ini memungkinkan peserta didik untuk berpasangan dan memberi pertanyaan kuis kepada temannya (Melvin L. Silberman, 2009: 250).

\section{Hipotesis Tindakan}

Berdasarkan hasil penelitian yang relevan dan kerangka pemikiran tersebut di atas maka dapat dirumuskan hipotesis tindakan: Penerapan model Active Learning tipe Index Card Match dapat meningkatkan hasil belajar matematika pada peserta didik kelas V SDN Cibentang 01, Bantarkawung, Brebes.

Penelitian ini dilaksanakan di SD Negeri Cibentang 01, Kecamatan Bantarkawung, Kabupaten Brebes pada bulan September 2019. Penelitian dilakukan sebanyak dua siklus. Masing-masing siklus dilakukan kegiatan pembelajaran sebanyak empat kali pertemuan dan pendampingan. Siklus 1 dilaksanakan pada bulan JuliSeptember siklus 2 bulan Oktober-Desember 2019. Subjek penelitian adalah peserta didik SDN Cibentang 01 Kelas 1 semester 1 tahun pelajaran 2019/2020 yang jumlahnya sebanyak 22 peserta didik. Dari jumlah tersebut terdiri dari 13 peserta didik laki-laki dan 9 peserta didik perempuan.

Pada model Kemmis dan Taggart, sesudah siklus selesai diimplementasikan, khususnya sesudah adanya refleksi, kemudian diikuti dengan adanya perencanaan ulang yang dilaksanakan dalam bentuk siklus tersendiri. Demikian seterusnya atau beberapa kali siklus. Siklus dihentikan apabila $75 \%$ dari jumlah peserta didik minimal sudah mendapatkan nilai 70 . Jika divisualisasi dalam bentuk gambar, penelitian tindakan model Kemmis dan MC Taggart, tampak pada gambar berikut ini. 


\section{METODE}

Penelitian Tindakan Kelas ini terdiri dari 2 Siklus yaitu siklus 1 dan 2 dengan Tahpan-tahapan sebagai berikut :

a. Perencanaan

Penyusunan rencana merupakan tindakan yang dilakukan untuk meningkatkan hasil belajar matematika pada peserta didik. Dengan melihat kondisi peserta didik dan permasalahan yang ada di kelas, maka salah satu upayayang dilakukan untuk meningkatkan hasil belajar peserta didik kelas 1 SD Negeri Cibentang 01 adalah dengan menggunakan model Active Learningtipe Index Card Match (ICM).

b. Tindakan dan Pengamatan

Selama proses pembelajaran berlangsung guru melakukan pembelajaran dengan menggunakan RPP sesuai langkah-langkah dalam Index Card Match. Sedangkan peneliti mengamati pelaksanaan tindakan dengan menggunakan lembar pengamatan yang telah disusun dan dipersiapkan sebelumnya.

c. Refleksi

Refleksi adalah kegiatan mengkaji dan mempertimbangkan hasil yang diperoleh dari pengamatan. Data atau hasil perubahan setelah adanya tindakan dianalisis kemudian dijadikan acuan perubahan atau perbaikan tindakan selanjutnya.

Apabila pada tindakan pertama hasil penelitian masih belum sesuai dengan tujuan yang diharapkan, maka dapat dilakukan perubahan rencana tindakan pada siklus berikutnya dengan mengacu pada hasil evaluasi sebelumnya. Dalam upaya memperbaiki tindakan pada siklus yang berikutnya perlu dilakukan pemeriksaan terhadap catatan-catatan hasil pengamatan

\section{HASIL DAN PEMBAHASAN}

Kegiatan awal dalam penelitian ini adalah melakukan pengamatan terhadap proses pembelajaran di SDN Cibentang 01, yang menjadi objek penelitian. Pengamatan dilakukan pada hari Senin tanggal 12 Agustus 2019 dan hari Kamis tanggal 15 Agustus 2019 dengan mengamati proses pembelajaran yang dilakukan guru tentang mengubah pecahan biasa menjadi berbagai bentuk pecahan yang diajarkan hanya dengan metode ceramah, dan penugasan saja.

Tabel 1. Data nilai peserta didik sebelum tindakan

\begin{tabular}{ccc}
\hline Nilai & $\begin{array}{c}\text { Jumlah } \\
\text { Peserta } \\
\text { didik }\end{array}$ & Persentase \\
\hline$<60$ & $\mathbf{1}$ & $4,54 \%$ \\
$\mathbf{6 0 - 6 9}$ & $\mathbf{7}$ & $31,82 \%$ \\
$>\mathbf{7 0}$ & $\mathbf{1 4}$ & $63,64 \%$ \\
\hline
\end{tabular}

Berdasarkan tabel di atas, hasil belajar Matematika kelas V SDN Randegan 02 sebelum menggunakan Active Learning tipe Index Card Match (ICM) proses pembelajaran adalah belum sesuai dengan nilai yang harus dicapai.

Tindakan yang akan dilaksanakan pada siklus I sesuai dengan perencanaan yaitu 2 kali pertemuan Data hasil pengamatan terhadap kegiatan guru pada pertemuan pertama dan kedua pada siklus I terdapat dalam lampiran.Pada pertemuan kedua, peserta didik diberikan tes hasil belajar untuk mengukur tingkat pemahaman mereka setelah melakukan kegiatan memasangkan kartu melalui Index Card Match (ICM). Tes yang dilakukan merupakan tes akhir yang digunakan untuk mengukur tingkat pemahaman peserta didik terhadap materi yang diajarkan. Hasil nilai tes akhir siklus I 
dapat dilihat pada lampiran. Rekap hasil belajar kognitif siklus I dapat dilihat pada tabel berikut :

Tabel 2. Data nilai peserta didik pada Siklus 1

\begin{tabular}{ccc}
\hline Nilai & $\begin{array}{c}\text { Jumlah } \\
\text { Peserta } \\
\text { didik }\end{array}$ & Persentase \\
\hline$<60$ & $\mathbf{0}$ & $0 \%$ \\
$60-69$ & 2 & $9,09 \%$ \\
$>70$ & 20 & $90,91 \%$ \\
\hline
\end{tabular}

Berdasarkan tabel di atas, jumlah peserta didik yang mendapatkan nilai $\leq 60$ sebanyak 0 peserta didik dengan persentase $0 \%$. Sebanyak 2 peserta didik mendapatkan nilai 61-69 yang tergolong cukup dengan persentase 9,09\%. Sedangkan yang mendapatkan nilai baik sebanyak 20 peserta didik dengan persentase $90,91 \%$. Sehingga diperoleh nilai rata-rata yang diperoleh meningkat menjadi 79,09

Tindakan yang akan dilaksanakan pada siklus II sesuai dengan perencanaan yaitu 2 kali pertemuan Rekap hasil nilai tes akhir siklus II dapat dilihat pada tabel berikut :

Tabel 3. Data nilai peserta didik pada Siklus II

\begin{tabular}{ccc}
\hline Nilai & Jumlah Peserta didik & Persentase \\
\hline$<60$ & $\mathbf{1}$ & $4,54 \%$ \\
$\mathbf{6 0 - 6 9}$ & $\mathbf{2}$ & $9,09 \%$ \\
$>\mathbf{7 0}$ & $\mathbf{1 9}$ & $86,36 \%$ \\
\hline
\end{tabular}

Berdasarkan tabel di atas, jumlah peserta didik yang mendapatkan nilai $\leq 60$ sebanyak 1 peserta didik dengan persentase 4,54\%. Sebanyak 2 peserta didik mendapatkan nilai 61-69 yang tergolong cukup dengan persentase 9,09\%. Sedangkan yang mendapatkan nilai baik sebanyak 19 peserta didik dengan persentase $86,36 \%$.

\section{PEMBAHASAN HASIL PENELITIAN}

Setelah menggunakan model Active Learning tipe Index Card Match (ICM) yang telah melalui siklus I kemudian berlanjut dengan siklus II, kualitas pendidikan menjadi baik. Hal ini dibuktikan dengan nilai kognitif peserta didik dalam proses pembelajaran semakin meningkat. Hasilnya nilai rata-rata kelas I meningkat dari 70,68 menjadi 79,09 pada siklus I dan meningkat lagi menjadi 84,95 pada siklus II.

Berikut adalah diagram nilai kognitif peserta didik.

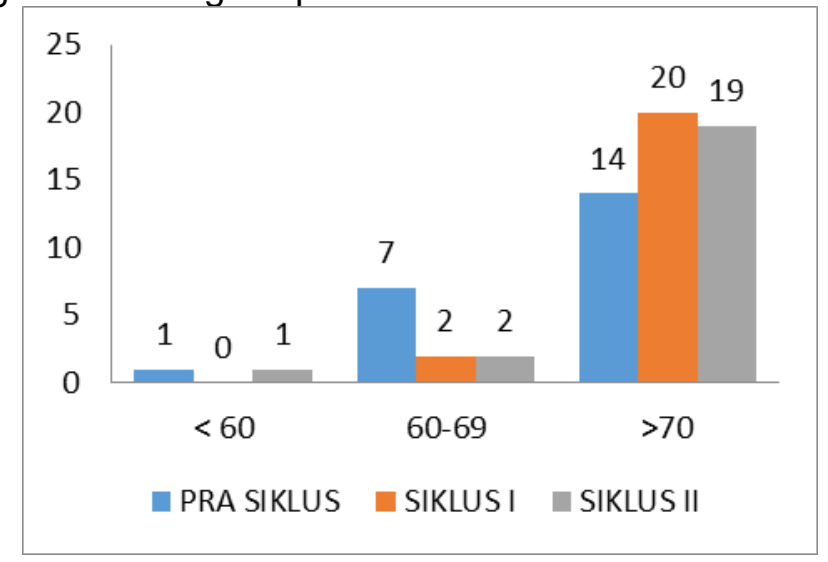




\section{Gambar 1. Grafik Peningkatan Nilai}

Dari diagram diatas, terlihat adanya peningkatan nilai rata-rata kognitif peserta didik, dari pra siklus, siklus I, dan sikus II. Peningkatannya terukur sebesar 20,25\%. Hal ini menunjukkan adanya peningkatan pemahaman peserta didik setelah menggunakan metode Index Card Match, sehingga pernyataan Hisyam Zaini (2008:69) mengenai salah satu kelebihan metode Index Card Match dapat meningkatkan hasil belajar peserta didik, baik secara kognitif maupun fisik adalah benar adanya.

Selain hasil belajar secara kognitif, hasil penilaian afektif juga mengalami peningkatan. Peningkatan tersebut ditandai dengan meningkatnya kepercayaan diri peserta didik, kerjasama, kemandirian dan managemen waktu dalam proses kegiatan belajar mengajar. Adapun rekapitulasi peningkatan tersebut adalah :

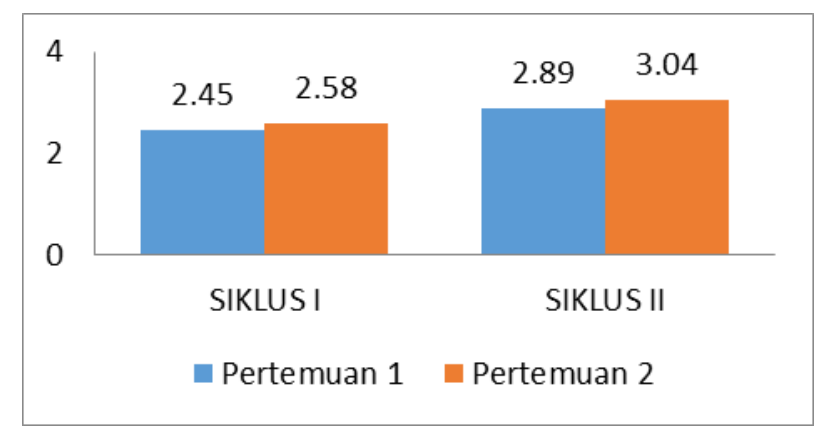

Gambar 2. Grafik Peningkatan Keatifan

Keaktifan peserta didik mengalami mengalami peningkatan yang besar. Sebelum menggunakan model Active Learning tipe Index Card Match (ICM) peserta didik terlihat pasif dan belum terlihat adanya interaksi belajar antara satu peserta didik dengan peserta didik lain. Setelah menggunakan model Active Learning tipe Index Card Match (ICM) terlihat peserta didik mulai mampu bekerja sama dengan peserta didik lain, lebih aktif dan percaya diri.

Pada penelitian ini mulai dari tahap pembelajaran pra siklus, siklus I, siklus II mengalami peningkatan nilai. Hasil penilaian afektif, dan penilaian kognitif pada penelitian meningkat maka dapat disimpulkan bahwa menggunakan metode yang efektif, efisien, dan variatif pembelajaran matematika dapat mencapai nilai yang memuaskan khususnya menggunakan model Active Learning tipe Index Card Match. Penerapan langkah-langkah metode Active Learning tipe Index Card Match dengan baik, sangat efisien dan efektif karena media yang mudah dibuat dan dioperasikan. Sehingga peserta didik merasa senang ketika akan mempelajari mata pelajaran matematika Penilaian yang telah dilakukan pada proses pembelajaran ini telah dibuat rata-rata sehingga dapat diketahui besar peningkatan yang telah terjadi. Rekapitulasi nilai afektif dan nilai kognitif dapat dilihat pada lampiran.

\section{SIMPULAN}

Berdasarkan hasil penelitian tindakan kelas yang telah dilakukan, dapat diambil kesimpulan bahwa penggunaan model Active Learning tipe Index Card Match (ICM) yang dimodifikasi dengan menggunakan metode diskusi, pemberian reward dan penambahan aturan saat bermain kuis dapat meningkatkan hasil belajar matematika pada materi operasi hitung pecahan desimal pada peserta didik kelas I SD Negeri Cibentang 01.

Pada siklus I digunakan model Active Learning tipe Index Card Match (ICM) dengan langkah-langkah sesuai dengan langkah yang disampaikan dalam buku Active 
Learning oleh Melvin Silberman. Dari penggunaan metode tersebut, rata-rata hasil belajar meningkat dari pra siklus 70,65 menjadi 78,47. Setelah dilakukan refleksi pada siklus I, pada siklus II dilakukan penambahan metode diskusi, penggunaan reward dan penambahan aturan saat kuis. Modifikasi yang dilakukan tersebut dapat meningkatkan hasil belajar afektif peserta didik terutama aspek kerjasama. Hasil belajar pun meningkat menjadi 84,06 . Total peningkatan dari pra siklus hingga siklus II mencapai $20,25 \%$.

\section{DAFTAR PUSTAKA}

Hisyam Zaini dkk. (2008). Strategi Pembelajaran Aktif. Yogyakarta: Pustaka Insani Madani \& CTSD.

Marsigit. (2011). Pengembangan Karakter dalam Pendidikan Matematika. Diakses dari http://www.academia.edu/2229723/Implementasi_Pendidikan_Karakter_dalam_ Pendidikan_Matematika. pada tanggal 18 Desember 2014, pukul.14.22 WIB

Pitadjeng. (2006). Pembelajaran Matematika yang Menyenangkan. Jakarta: Jenderal Pendidikan Tinggi Departemen Pendidikan Nasional

Rusman. (2010). Model-Model Pembelajaran Mengembangkan Profesionalisme Guru. Jakarta: Rajawali Pers.

Silberman, Melvin. (2009). Active Learning 101 Strategi Pembelajaran Aktif. Yogyakarta : Insan Madani

Soedjadi. (1999). Kiat Pendidikan Matematika di Indonesia. Jakarta : Direktorat Jendral Pendidikan Tinggi Departemen Pendidikan Nasional

Sugiyono. (2008). Metode Penelitian Kunatitatif Kualitatif dan $R \& D$. Bandung Alfabeta Suharsimi Arikunto. (2006). Dasar-Dasar Evaluasi Pendidikan. Jakarta: Bumi 